\title{
Construction of Social Reality for Physical Distancing During the COVID-19 Pandemic
}

\section{Konstruksi Realitas Sosial Atas Physical Distancing Selama Pandemi COVID-19}

\author{
Maylanny Christin ${ }^{1}$, Dasrun Hidayat ${ }^{2}$, Atie Rachmiatie ${ }^{3}$ \\ ${ }^{1}$ Universitas Telkom, Jl. Telekomunikasi Nomer 1, Terusan Buah Batu, Bandung* \\ Email: maylannychristin@telkomuniversity.ac.id \\ ${ }^{2}$ Universitas Adhirajasa Reswara Sanjaya, Jl. Sekolah International Nomer 1-4, Antapani, \\ Bandung \\ Email: dasrun@ars.ac.id \\ ${ }^{3}$ Universitas Islam Bandung, Jl. Taman Sari Nomer 1, Bandung \\ Email: rachmiatie@gmail.com
}

\begin{abstract}
The focus of the research is communication behavior in the Physical Distancing phase during COVID-19. Physical Distancing is a government policy intended to reduce the spread of COVID-19. The research objective was to analyze the knowledge and communication behavior of the people. The method used is phenomenology with a qualitative approach. Involving the people of Bandung city as research informants as many as 11 people. The technique of collecting data through online interviews is that physical distancing is still in place. The results showed that the physical distancing phase of the community's communication behavior can be categorized into three groups including active, sympathetic, and indifferent groups. Active group means being concerned with finding information and implementing Physical Distancing policies. The sympathy group is receiving Physical Distancing information, but not fully carrying out Physical Distancing. Informant groups are indifferent or passive informants in seeking information and do not carry out Physical Distancing. Another communication behavior that the Physical Distancing phase activities is carried out online using digital media. Informants admit that Physical Distancing activities have changed the dimension of interpersonal communication which requires the presence of distance, but the Physical Distancing phase has turned virtual. This communication behavior builds a shared experience that online communication encourages the formation of virtual relationships. The results of this study are expected to contribute to online communication competence as an effort to maintain the quality of communication even though it is done online.
\end{abstract}

Keywords: communication dimension, COVID-19, physical distancing, virtual relationship

\begin{abstract}
Abstrak
Fokus penelitian adalah perilaku komunikasi pada fase Physical Distancing selama COVID-19. Physical Distancing merupakan kebijakan pemerintah yang dimaksudkan untuk mengurangi penyebaran COVID-19. Tujuan penelitian untuk menganalisis pengetahuan dan perilaku komunikasi masyarakat. Metode yang digunakan fenomenologi dengan pendekatan kualitatif. Melibatkan masyarakat kota Bandung sebagai informan
\end{abstract}


penelitian sebanyak 11 orang. Adapun teknik pengumpulan data melalui wawancara daring mengingat masih diberlakukannya Physical Distancing. Hasil penelitian menunjukkan bahwa perilaku komunikasi masyarakat fase Physical Distancing dapat dikategorikan dalam tiga kelompok meliputi kelompok aktif, simpati, dan acuh. Kelompok aktif artinya peduli dengan mencari informasi dan menjalankan kebijakan Physical Distancing. Kelompok simpati yaitu menerima informasi Physical Distancing, namun tidak sepenuhnya menjalankan Physical Distancing. Kelompok informan acuh atau informan pasif dalam mencari informasi dan tidak menjalankan Physical Distancing. Perilaku komunikasi lainnya bahwa aktivitas fase Physical Distancing dilakukan secara daring dengan menggunakan media digital. Informan mengakui bahwa aktivitas Physical Distancing telah merubah dimensi komunikasi interpersonal yang mensyaratkan kehadiran jarak, namun fase Physical Distancing berubah menjadi virtual. Perilaku komunikasi tersebut membangun pengalaman bersama bahwa komunikasi daring mendorong terbentuknya hubungan virtual. Hasil penelitian ini diharapkan dapat berkontribusi terhadap kompetensi komunikasi daring sebagai upaya menjaga kualitas komunikasi meskipun dilakukan secara daring.

Kata Kunci: COVID-19, dimensi komunikasi, hubungan virtual, physical distancing

\section{Pendahuluan}

Seluruh dunia menyerukan tentang pentingnya program kesehatan publik. Hal ini menyusul pandemi COVID-19 yang sudah menjadi masalah kesehatan global. World Health Organization (WHO) melansir hingga 1 April tercatat total kasus COVID-19 mencapai 823.626 (WHO, 2020). Tingginya angka kasus COVID-19, maka WHO mengeluarkan instruksi agar tiap negara menerapkan kebijkan lokal untuk mengurangi, memperlambat, atau menghentikan penyebaran COVID-19.

WHO merilis bahwa negara-negara yang terpapar COVID-19 memberlakukan serangkaian langkah-langkah pencegahan dan memutus matarantai COVID-19 (WHO, 2020). Tentu saja langkah yang diambil berbeda-beda disesuaikan dengan kondisi lokal tentang perkembangan pandemi COVID-19. Tiap negara diberikan kebebasan untuk menentukan tindakan yang harus diambil. Meski demikian, tiap negara diminta untuk meninjau ulang tiap kebijakan secara berkala dengan menyesuaikan situasi pandemi COVID-19. Kebijakan yang diambil dapat diterapkan di tingkat lokal, regional atau nasional di tiap negara. Kebijakan juga disesuaikan dengan kebutuhan, dan mempertimbangkan aspek-aspek seperti budaya, lingkungan hidup, medan, dan akses sumber daya manusia, seperti tenaga medis.

Adapun langkah-langkah yang selama ini dilakukan di tiap negara yakni membuat kampanye mencegah COVID-19 dengan hidup sehat, menjalankan protokol kesehatan melalui kebiasaan mencuci tangan, menggunakan masker tiap akan keluar rumah, melakukan karantina atau isolasi diri jika merasa tidak sehat, konsultasi dengan tenaga medis, jaga jarak atau Physical Distancing, hingga kebijakan lockdown. Di Indonesia juga menerapkan kebijakan Pembatasan Sosial Berskala Besar atau PSBB (Pratama \& Hidayat, 2020) 
Berbagai kebijakan untuk menghentikan penyebaran COVID-19, kebijakan menjaga jarak fisik ketika melakukan komunikasi atau Physical Distancing merupakan kebijakan yang menarik untuk dikaji karena tidak semua masyarakat siap menjalankan Physical Distancing. Kendala yang dirasakan bahwa masyarakat sudah terbiasa dengan komunikasi langsung tanpa adanya jarak fisik karena hal ini akan mengurangi komunikasi antar manusia secara langsung (Kresna \& Ahyar, 2020). Kegagalan Physical Distancing dikarenakan faktor budaya yang ada di tengah masyarakat (La Ode Arwah Rahman, 2020). Bahkan masyarakat kota Bandung sebagai lokasi penelitian ini memiliki budaya kebersamaan atau guyub yang sangat kental (Rosidi, 2000). Diantara karakteristik budaya tersebut adalah keakraban dan tidak adanya jarak fisik dalam berkomunikasi. Misalnya, bertemu dan menyapa tidak hanya mengucapkan salam, akan tetapi juga berjabatan tangan, bahkan saling berpelukan. Kebiasaan tersebut berubah setelah adanya COVID-19. Saat ini, untuk menyapa sesama teman, kerabat, cukup dengan menempelkan kedua belah telapak tangan di dada, menyilangkan tangan kanan di dada atau dengan cara lainnya. Tentu saja perilaku ini merubah nilai-nilai komunikasi tatap muka yang menysaratkan adanya sentuhan atau kontak fisik sehingga membangun kedekatan atau keakraban (Hidayat, 2012). Adanya kebijakan Physical Distancing, seakan merubah nilai keakraban dan kehangatan menjadi rasa kekhawatiran, kecemasan, bahkan ketakutan dalam berkomunikasi.

Physical Distancing tetap harus dilakukan sampai waktu yang belum bisa dipastikan. Selama itu pula masyarakat diharapkan mampu menjaga jarak ketika berkomunikasi, meskipun hal ini akan mengurangi kuantitas dan kualitas berkomunikasi. Realitas ini harus dibayar mahal berupa berkurangnya kontak sosial dengan orang terdekat. Namun demikian, masyarakat tetap diminta untuk menjalankan Physical Distancing meskipun dengan ragam pengetahuan dan penerimaan dari masyarakat. Kondisi ini tentu saja berkaitan erat dengan motivasi masyarakat dalam menjalankan Physical Distancing. Selaras dengan hasil penelitian sebelumnya bahwa masyarakat menjalankan Physical Distancing berbeda sesuai kondisi tiap individu, misalnya menerima Physical Distancing sebagai kontrol, empati, dan sekedar untuk informasi (Pfattheicher et al., 2020). Apapun kondisinya langkah ini penting dilakukan sebagai upaya mendukung program pemerintah dalam memutus matarantai COVID-19.

Menjaga jarak secara fisik adalah program mengatur posisi ketika berkomunikasi dengan orang yang bukan anggota keluarga, setidaknya satu meter, Adrian (2020) dalam (Pratama \& Hidayat, 2020). Di Indonesia, langkah ini sudah diterapkan disemua institusi atau lembaga, baik pemerintah maupun swasta. Bahkan untuk mendukung program Physical Distancing, pemerintah mengeluarkan kebijakan belajar dari rumah atau Study from Home (SfH), ibadah dari rumah, dan bekerja dari rumah Work from Home (WfH) (Pratama \& Hidayat, 2020). Kebijakan ini dimaksudkan untuk mengurangi kontak sosial berskala besar, sehingga mampu mengurangi kerumunan atau keramaian. Bahkan pemerintah Indonesia baru-baru ini juga mengeluarkan instruksi tentang PSBB atau Pembatasan Sosial Berskala Besar. Langkah ini baru diterapkan dibeberapa kota dan kabupaten yang dinilai rawan atau zona merah COVID-19. PSBB sebenarnya hampir mirip dengan kebijakan lockdown yang diterapkan di beberapa negara. Kebijakan ini sama-sama 
bertujuan untuk membatasi aktivitas masyarakat di luar dan mengganti aktivitas dari rumah (Yunus \& Rezki, 2020). PSBB maupun lockdown bertujuan untuk mengurangi, bahkan memutus matarantai penyebaran COVID-19.

Dalam mensukseskan kebijakan Physical Distancing, pemerintah juga mendorong masyarakat untuk membiasakan berkomunikasi melalui teknologi internet atau komunikasi daring. Istilah lainnya adalah komunikasi berbasis Information Communication and Technology atau ICT (Fitri \& Putra, 2019). Pendekatan komunikasi melalui ICT memang sudah terjadi sebelum adanya pandemi. Selama pandemi situasinya berubah menjadi lebih masif karena hampir semua aktivitas berbasis jaringan internet. Misalnya belajar dari rumah secara daring, belanja daring, bekerja secara daring, dan silaturahim dengan tentangga dekatpun juga menggunakan teknologi berbasis jaringan internet. COVID-19 juga merubah perilaku sehari-hari dengan menerapkan protokol kesehatan seperti menggunakan masker (Eikenberry et al., 2020). Selama pandemi merubah perilaku masyarakat dalam mengkonsumsi makanan yang bernutrisi (Y1lmaz et al., 2020) Potret perilaku masyarakat selama COVID-19, tentu saja secara perlahan akan membangun hubungan secara virtual baik dalam lingkup terkecil yakni keluarga maupun masyarakat. Hubungan virtual dapat diartikan sebagai ikatan sosial secara virtual (Ode \& Nurhaliza, 2020). Ikatan sosial secara virtual sebagai hasil yang diperolah dari interaksi yang dimediasi dalam lingkungan media digital (Hidayat, 2012). Hubungan virtual terbentuk dari interaksi antar individu yang menggunakan media internet sehingga mendorong lahirnya komunitas virtual. Komunitas yang di dalamnya terdiri dari orang-orang yang menggantungkan aktivitas komunikasi secara maya (Utami \& Silalahi, 2013). Komunikasi secara daring atau komunikasi berbasis ICT juga akan merubah dimensi komunikasi masyarakat. Misalnya, perubahan terhadap dimensi komunikasi interpersonal yang berorientasi pada kehadiran fisik (Hidayat, 2012) kemudian berubah menjadi ruang dan waktu secara virtual. Selain itu, nilai kedekatan, keakraban yang biasanya hadir dalam jarak personal, dan akhirnya berubah menjadi jarak sosial. Hal ini pula yang menjadi dasar bahwa kebijakan Physical Distancing selama pandemi COVID-19 menarik untuk dikaji sesuai dengan kondisi masyarakat.

Berdasarkan beberapa penelitian sebelumnya yang dipaparkan pada bagian sebelumnya, maka peneliti dapat menarik perbedaan sekaligus kebaruan penelitian pada pengalaman masyarakat dalam menjalankan Physical Distancing. Pengalaman terkait pengetahuan dan perilaku komunikasi masyarakat fase Physical Distancing. Fenomena ini menarik karena hingga saat ini trend COVID-19 masih belum menurun sedangkan Physical Distancing salah satu cara mencegah penyebaran. Tujuan dari penelitian untuk menganalisis pengetahuan masyarakat tentang Physical Distancing dan perilaku komunikasi masyarakat dalam fase Physical Distancing. Tujuan penelitian tersebut sekaligus sebagai aspek-aspek dari obyek yang akan dikaji. Diharapkan hasil penelitian berupa pengetahuan dan perilaku masyarakat dalam memaknai Physical Distancing dapat berkontribusi terhadap arah kebijakan yang akan dirumuskan oleh pemerintah selama menerapakan Physical Distancing, baik ketika memasuki masa adaptasi kebiasaan baru atau new normal, maupun pasca pandemi. Misalnya, melakukan peningkatan 
keahlian komunikasi menyusul aktivitas daring sebagai bagian dari penerapan Physical Distancing.

\section{Metode Penelitian}

Penelitian ini mengkaji tentang konstruksi realitas sosial atas physical distancing selama pandemi COVID-19. Objek yang diteliti terkait pengetahuan dan perilaku komunikasi masyarakat sehingga membangun konsensus bersama tentang pengalaman komunikasi selama fase Physical Distancing. Penelitian menggunakan studi fenomenologi dengan pendekatan kualitatif. Penelitian kualitatif menekankan pada realitas yang dibangun atas hasil pengamatan lapangan yang sifatnya alamiah atau tanpa seting (Pradsmadji \& Irwansyah, 2019). Realitas yang dimaksud adalah realitas physical distancing meskipun selama penelitian ini tidak dilakukan pengamatan berperan serta, akan tetapi pengamatan secara tidak langsung dengan memanfaatkan berbagai media massa. Tindakan ini dilakukan mengingat situasi di Kota Bandung masih dalam status pandemi COVID-19.

Peneliti atau penomenolog atau peneliti fenomenologi secara aksiologi bertujuan untuk mengkonstruksi pengalaman antar informan sehingga pengalaman tersebut mampu membangun konsensus bersama terkait kebijakan jaga jarak fisik (physical distancing) yang terbangun selama pandemi COVID-19. Fenomenologi bertujuan mengeksplorasi pengalaman tiap individu (Sari, 2020). Pengalaman yang dimaksud adalah pengalaman informan selama melakukan jarak fisik yang dilatar belakangi oleh motif-motif tertentu. Fenomenologi menekankan pada motif individu atas tindakan komunikasi (Supraja, 2012).

Fenomenologi secara epistimologi mensyaratkan adanya keterlibatan peneliti dalam pengumpulan data melalui wawancara. Pada penelitian ini wawancara dilakukan bersama masyarakat kota Bandung secara daring. Hal ini dipilih sebagai bentuk dukungan terhadap program pemerintah membatasi jarak sosial selama pandemi COVID-19. Wawancara secara tidak berperan serta karena tidak adanya keterlibatan dengan kegiatan subyek penelitian. Wawancara terdiri dari wawancara berperan serta atau adanya keterlibatan, dan wawancara tanpa berperan serta (Yin, 2014). Untuk melengkapi hasil wawancara, peneliti juga menggunakan kajian literar dari berbagai sumber artikel atau kajian terdahulu terkait perkembangan kasus COVID-19.

Informan atau subyek penelitian dipilih secara purposiv dengan keterlibatan 11 informan yang berdomisili di kota Bandung dan sekitarnya. Adapun pertimbangan kriteria informan sekaligus pemilihan lokasi tersebut karena berdasarkan hasil survei bahwa pada 1.522 orang di Pulau Jawa, sebanyak 64,3\% merasa cemas \& depresi karena pemberlakuan Physical Distancing, dan jumlah terbesar ada di Jawa Barat. Selain itu, sebagai Ibu kota Provinsi Jawa Barat Bandung memiliki Jumlah penduduk terbesar ke dua setelah Bogor. Tipologi masyarakat Jawa Barat yang di dominasi masyarakat Sunda Dilihat dari segi jumlahnya orang Sunda merupakan kelompok kedua terbesar dengan jumlah 36.701 .670 orang $(15.5 \%)$ setelah orang Jawa (Tengah dan Timur) sebanyak 95.217.022 orang atau 40.2\%. Dilihat dari teori etno simbolik yang dikemukakan Smith $(1986,1998)$ dalam (Rosidi, 2000) Sunda merupakan etnis terbesar kedua- 
setelah Jawa-yang merupakan core-ethnie dalam pembentukan negara bangsa Indonesia. Orang Sunda berada di propinsi Jawa Barat dan bahasa Sunda yang murni dan halus ada di wilayah Priangan.

Budaya masyarakat Priangan adalah Budaya guyub/gotong royong dapat dilihat dari sudut pandang Cultural Sociology sebagai alat analisis yang mencakup identitas, memori kolektif, klasifikasi sosial dan logika bertindak (Rosidi, 2000). Identitas berkaitan dengan representasi karakter individu dan kelompok yang kedua nature-nya dapat dikatakan sama secara tindakan. Kebutuhan untuk menyatakan sesuatunya secara tatap muka penting bagi masyarakat Sunda. Namun adanya Physical Distancing telah membuat budaya tersebut terhambat.

Data penelitian dikumpulan melalui wawancara dan kajian literatur. Teknik wawancara bertujuan untuk mendapatkan data primer. Wawancara dilakukan secara daring karena situasi Kota Bandung masih dalam kategori zona merah. Sedangkan data sekunder diperoleh dari literatur meliputi artikel jurnal dan website terkait COVID-19. Data-data tersebut diolah atau dianalisis dengan proses analisis meliputi tahapan konstruk data ke-satu, konstruk data ke-dua, dan konstruk data ke-tiga (Hidayat \& Hafiar, 2019). Konstruk data ke-satu peneliti membuat transkrip hasil wawancara bersama informan. Hasil tersebut kemudian diolah kembali dengan melakukan klasifikasi atau pengelompokkan data berdasarkan sub-tema data. Langkah ini disebut pula sebagai tahap konstruk data ke-dua. Pada tahap akhir atau konstruk data ke-tiga, peneliti membuat analisis pada bagian pembahasan terkait temuan yang mampu menjelaskan tujuan penelitian.

\section{Hasil Penemuan dan Diskusi}

Aspek pertama yang dijelaskan oleh para informan terkait dengan tujuan penelitian adalah mengenai pendapat mereka tentang Physical Distancing. Bagian ini penting untuk digali sebelum menanyakan perihal perilaku informan pada fase Physical Distancing. Pendapat informan juga sebagai bukti bahwa mereka mengetahui tentang Physical Distancing. Berdasarkan hasil wawancara secara daring, informan mengatakan bahwa mereka mengetahui apa itu Physical Distancing.

Physical Distancing adalah kebijakan pemerintah yang dikeluarkan menyusul adanya pandemi COVID-19". Langkah ini diambil untuk menghentikan penyebaran virus corona. Biasanya sebelum pandemi sering kumpul-kumpul, ketika pandemi tidak dilakukan lagi, ya untuk jaga jarak karena virus corona bisa menyebar dari orang yang menjadi lawan ketika berbicara (Sandi, 07 Juni 2020).

Informan berikutnya menuturkan hal yang sama tentang ap aitu Physical Distancing.

Peraturan tentang viruscorona yang diwajibakan oleh pemerintah karena Indonesia termasuk negara pandemi. Menurut saya aturan ini bagus untuk mencegah virus dan memang pemerintah harus tegas membuat aturan agar masyarakat tidak memandang sederhana corona ini. Apalagi katanya virus ini menularnya dari intereksi langsung antar manusia (Mega, 09 Juni 2020). 
Ragam pendapat masyarakat mengenai Physical Distancing membuktikan bahwa masyarakat mengetauhi tentang COVID-19. Meskipun tidak menjelaskan secara rinci tentang COVID-19, akan tetapi mereka mengetahui bahwa asal-usul kebijakan Physical Distancing menyusul adanya kasus global COVID-19. COVID19 adalah istilah dari coronavirus. Virus ini termasuk virus berbahaya bahkan dapat mengakibatkan korban meninggal dunia (Beniac et al, 2006). Kasus virus mematikan ini mulanya terjadi di Cina Tengah, tepatnya kota Wuhan, akhir tahun 2019 lalu.

Pengetahuan masyarakat tentang COVID-19 diakui diperolah dari media massa, baik media konvensional maupun kontemporer. Media konvensional yang digunakan berupa televisi dan surat kabar cetak. "Informasi corona petama kali dari nonton televisi." Senada dengan ungkapan informan berikut "Suami baca koran dan cerita kesaya." Sedangkan media lain yang sering diakses untuk mendapatkan informasi COVID-19 adalah media sosial. "Saya dari WhatsApp, ada juga dari instagram." Mereka mengakui informasi lebih banyak diterima dari media sosial. Dikemukakan Bode (2015) bahwa media sosial memungkinkan individu untuk mendapatkan informasi dan belajar (dalam Rahardjo et al., 2020). Media sosial berkontribusi terhadap pengetahuan masyarakat tentang COVID-19. Kelebihan media sosial yang mampu menyajikan konten dalam berbagai bentuk, selain tulisan juga audiovideo, menjadi daya tarik masyarakat untuk mengakses dan mencari informasi COVID-19. Perilaku komunikasi masyarakat dalam mencari dan menerima informasi juga digambarkan dalam teori pemrosesan informasi sosial. Teori yang digagas oleh Joseph Walther ini memiliki asumsi bahwa tiap individu menggunakan teknologi karena didasari oleh kebutuhan. Adanya kebutuhan mendorong seseorang mengakses media sosial dengan tujuan mendapatkan pengetahuan (Griffin, 2011). Teori pemrosesan informasi merupakan perkembangan teori CMC atau Computer Mediated Communication. Teori yang menyatakan bahwa hubungan dibangun melalui media komputer berbasis teknologi internet (West \& Turner, 2013).

Cara masyarakat dalam memenuhi kebutuhan tentang informasi COVID-19 juga dapat dijelaskan melalui teori uses and gratification. Teori yang berada diwilayah teori objektif dengan tradisi sosiopsikologi ini fokus berbicara tentang media dan efek. Teori ini berasumsi bahwa khalayak atau masyarakat bersifat aktif dalam memilih saluran media (Griffin, 2011). Tindakan ini dilandasi oleh kebutuhan (need) tiap khalayak berbeda-beda. Karenanya, khalayak memilih media dengan harapan dapat memberikan kepuasan terhadap kebutuhan akan informasi. Dalam koteks hasil penelitian ini adalah kepuasan khalayak untuk mendapatkan informasi terkait COVID-19. Dengan kondisi masyarakat yang terpapar oleh berbagai media massa mendorong perilaku selektif memilih media.

Perilaku selektif memilih saluran media diakui informan sebagai tindakan preventif agar terhindar dari berita bohong atau hoax. Berita hoax diartikan sebagai berita tanpa fakta dan tidak dapat dipertanggung jawabkan (Hidayat \& Anisti, 2015). Menurut informan banyaknya informasi tentang COVID-19 di media massa khsusnya media sosial, membuka peluang adanya berita hoax. Situasi ini pernah disampaikan pada kajian terdahulu bahwa terdapat sekitar 50 berita hoax tentang COVID-19 (Rahayu \& Sensusiyati, 2020). Dari total berita hoax tentang COVID- 
19 berita yang paling banyak terjadi pada tanggal 24 Maret 2020. Situasi ini tepat diawal ketika Indonesia terpapar COVID-19 setelah sebelumnya pada tanggal 16 Maret Presiden Jokowi mengumumkan korban pertama COVID-19 yang terjadi di Depok. Tentu saja masyarakat sangat menyayangkan adanya berita hoax di tengah masyarakat sedang cemas dan panik akibat adanya COVID-19. Tindakan ini justru menambah kepanikan bahkan berubah jadi perasaan takut berlebihan. Oleh karena itu, pemerintah melalui kementrian komunikasi dan informasi bekerja cepat mengusut dan menghentikan kasus berita hoax di tengah pandemi COVID-19. Tabel 1 menyebutkan bahwa hoax selama periode Januari-Maret 2020 yang diambil dari hasil penelitian sebelumnya.

Tabel 1. Periode berita hoax Januari-Maret 2020

\begin{tabular}{lll}
\hline Tanggal & Jumlah & Persentase (\%) \\
\hline 24 Maret 2020 & 10 & 20,00 \\
\hline 23 Maret 2020 & 2 & 4,00 \\
\hline 22 Maret 2020 & 2 & 4,00 \\
\hline 21 Maret 2020 & 2 & 4,00 \\
\hline 20 Maret 2020 & 1 & 2,00 \\
\hline 15 Maret 2020 & 1 & 2,00 \\
\hline 14 Maret 2020 & 1 & 2,00 \\
\hline 12 Maret 2020 & 1 & 2,00 \\
\hline 10 Maret 2020 & 4 & 8,00 \\
\hline 08 Maret 2020 & 1 & 2,00 \\
\hline 06 Maret 2020 & 1 & 2,00 \\
\hline 05 Maret 2020 & 1 & 2,00 \\
\hline 04 Maret 2020 & 1 & 2,00 \\
\hline 02 Maret 2020 & 1 & 2,00 \\
\hline 23 Februari 2020 & 1 & 2,00 \\
\hline 03 Februari 2020 & 1 & 2,00 \\
\hline 02 Februari 2020 & 1 & 2,00 \\
\hline 01 Februari 2020 & 2 & 4,00 \\
\hline 31 Januari 2020 & 1 & 2,00 \\
\hline 30 Januari 2020 & 1 & 2,00 \\
\hline 29 Januari 2020 & 1 & 2,00 \\
\hline 28 Januari 2020 & 4 & 8,00 \\
\hline 27 Januari 2020 & 4 & 8,00 \\
\hline 26 Januari 2020 & 2 & 4,00 \\
\hline 23 Januari 2020 & 2 & 4,00 \\
\hline 20 Januari 2020 & 1 & 2,00 \\
\hline Jumlah & 50 & 100 \\
\hline
\end{tabular}

Sumber: (Rahayu \& Sensusiyati, 2020) 
Berdasarkan 50 kasus berita hoax ditemukan pula titik-titik atau tempat terjadinya berita hoax. Adapun kota yang paling banyak terpapar berita hoax adalah Jakarta. Hal ini selaras dengan situasi Jakarta yang memiliki jumlah kasus tertinggi dibandingkan daerah atau kota lainnya.

Tabel 2. Kota Tempat Kejadian Hoax

\begin{tabular}{llll}
\hline \multicolumn{1}{c}{ Kota } & & Jumlah & Persentase (\%) \\
\hline Bali & 1 & 2,00 & 2,00 \\
Bau - bau & 1 & 2,00 \\
Cimahi & 1 & 2,00 \\
Cipali & 1 & 64,00 \\
DKI Jakarta & 32 & 2,00 \\
Halmahera & 1 & 2,00 \\
Jember & 1 & 2,00 \\
Makassar & 1 & 4,00 \\
Mataram Lombok & 1 & 2,00 \\
Mojokerto & 1 & 2,00 \\
Muntok Bangka & 1 & 4,00 \\
Tangerang & 2 & 2,00 \\
Singkawang & 1 & 2,00 \\
Soe -NTT & 1 & 2,00 \\
Solo & 1 & 4,00 \\
Surabaya & 2 & 4,00 \\
Yogyakarta & 2 & 100 \\
JUMLAH & $\mathbf{5 0}$ &
\end{tabular}

Sumber: (Rahayu \& Sensusiyati, 2020)

Selain media yang digunakan beragam, informasi yang dibutuhkan dan diterima masyarakat tentang COVID-19 juga bervariasi. Mulai dari informasi penjelasan apa itu COVID-19, pencegahan, dan pengobatannya. Menurut mereka bahwa informasi yang diterima dari berbagai media menjelaskan gejala COVID-19 seperti batuk, infeksi saluran pernapasan yang umumnya ringan, seperti pilek (Yunus \& Rezki, 2020). Jenis informasi lainnya yang diterima masyarakat dan diakses di media sosial yakni seputar pencegahan COVID-19. Menurut pengakuan informan, pencegahan COVID-19 dapat dilakukan dengan mengikuti kebijakan pemerintah seperti jaga jarak (Physical Distancing), menggunakan masker ketika keluar rumah, dan melakukan tiap aktivitas dari rumah (work from home). "Pantau informasi ya supaya tau gimana cara mencegahnya." Informan lain mengatakan "Saya tau tu sudah ada Physical Distancing." Selaras dengan informan berikutnya "Ikuti anjuran pemerintah jaga jarak, pake masker, rajin cuci tangan." Pengakuan para informan tersebut menjadi bukti bahwa mereka mengetahui cara memutus penyebaran COVID-19. Informasi lain yang diakses adalah cara pengobatan pasien COVID-19. Berdasarkan pengetahuan informan, bahwa pasien COVID-19 harus melakukan isolasi di rumah sakit atau isolasi mandiri. Pasien juga diminta untuk selalu menggunakan masker, dan mengkonsumsi makanan cukup vitamin.

Terdapat beberapa langkah pengobatan pasien COVID-19. Diantaranya prosedur yang baru ini ditemukan adalah dengan menggunakan plasma darah. Pengobatan ini dimulai dari memilih donor. Adapun syarat donor yaitu mereka yang pernah terinfeksi COVID-19 dan berujung sembuh. Kemudian langkah berikutnya melakukan transfusi plasma darah. WHO melansir bahwa pasien COVID-19 sebenarnya bisa sembuh apabila menggunakan prosedur pengobatan 
yang tepat (WHO, 2020). Bahkan 90 persen bisa dikatakan sembuh dari COVID19. Oleh karena itu penanganan yang tepat sangat diutamakan. Misalnya, pasien mengkonsumsi obat sesuai gejalanya. Tidak semua pasien mengalami infeksi berat, akan tetapi ada pula yang mengalami infeksi ringan. Tentu penanganannya pun berlaku berbeda termasuk asupan yang dibutuhkan, seperti antivirus, vitamin, dan lainnya.

Pandemi COVID-19 menciptakan krisis akut di belahan dunia. Upaya yang dilakukan untuk menghambat percepatan pertumbuhan COVID-19, sebanyak 213 negara di dunia termasuk Indonesia, menyerukan adanya perubahan dalam kebiasaan sosial. Perubahan yang dimaksud adalah perilaku yang disebut Physical Distancing atau menjaga jarak dalam berinteraksi dengan orang lain. Jarak fisik dinilai mampu mengurangi kemungkinan penyebaran COVID-19. Physical Distancing dapat dikatakan sebagai program manajemen krisis yakni tindakan yang harus dilakukan oleh pemerintah untuk memutus matarantai virus. Manajemen krisis sendiri diartikan sebagai tindak penangan terhadap kondisi yang tidak mengungtungkan bagi perusahaan maupun lembaga (Luhukay, 2013). Krisis dapat mengganggu transaksi dan menggangu keberlangsungan perusahaan, organisasi atau lembaga (Fajar, 2011). Krisis membutuhkan penanganan sesuai dengan tingkatan krisis (Sa'diyah, 2013). Jika krisis tersebut sudah masuk pada level akut maka secepat mungkin harus diatasi. Penanganan krisis membutuhkan tahapan, mulai dari pengumpulan data, analisis situasi, identifikasi krisis, menentukan program strategi penanganan krisis, pelaksanaan program, dan evaluasi proses pelaksanaan program krisis (Smith, 2005). Kondisi krisis COVID-19 di Indonesia dapat dikatakan memasuki level akut. Situasi yang membutuhkan penanganan agar roda pemerintahan tidak terganggu. Pemerintah secara cepat dan tegas mengikuti program dunia yang digagas oleh WHO berupa Physical Distancing. Mulanya program ini disebut Social Distancing, kemudian dirubah menjadi Physical Distancing. Perubahan ini dimaksudkan agar masyarakat lebih mudah memahami bahwa yang perlu dijaga adalah jarak fisik ketika melakukan interaksi. Jarak fisik yang tidak dijaga disinyalir dapat mempermudah penyebaran viruscorona.

Physical Distancing direkomendasikan dan dikampanyekan oleh lembagalembaga nasional di ratusan negara berikut lembaga internasional yaitu WHO. Untuk menjalankan kebijakan tersebut tiap negara diminta untuk mengurangi aktivitas di luar rumah. Sebaliknya semua aktivitas dilakukan dari rumah termasuk ibadah. Bahkan di Indonesia sejak bulan April hingga Juni di beberapa lokasi masih menjalankan aturan PSBB. Kebijakan ini untuk mendukung program WHO tentang Physical Distancing. PSBB diharapkan mamu menekan dan memutus penyebaran COVID-19.

Kriteria perilaku masyarakat fase Physical Distancing terdiri dari tiga kategori meliputi informan aktif, simpati, dan acuh. Informan aktif yaitu mereka yang secara sadar, peduli dengan mencari informasi dan menjalanan kebijakan Physical Distancing. Kelompok informan simpati adalah informan yang menerima informasi Physical Distancing, namun tidak sepenuhnya menjalankan Physical Distancing. Kelompok informan acuh atau informan pasif mencari dan mengetahui apalagi menjalankan Physical Distancing. 


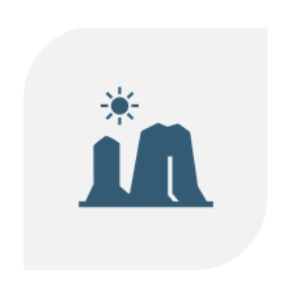

Aktif

(Sadar, Peduli, dan Kontrol)

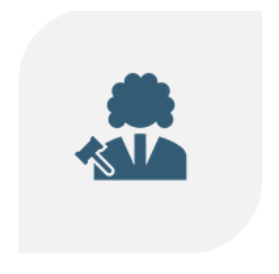

Simpati

(Menerima, Kondisional, dan Cultural Sociology)

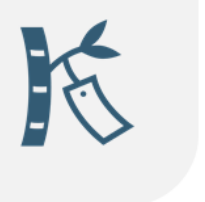

Acuh

(Pasif dan Tidak Peduli)

Gambar 1: Motif Physical Distancing

(Sumber: Hasil Penelitian, 2020)

Informan yang tergolong aktif adalah informan yang memiliki motiviasi dan kesadaran bahwa dirinya membutuhkan informasi tentang Physical Distancing sebagai kontrol diri dan keluarga. "cari dan juga aktif menerima informasi itu untuk jaga-jaga aja sih, nggak untuk saya tapi juga keluarga, makanya saya juga aktif menyampaikan informasi physical distancing itu.". Motif mengakses informasi sebagai kontrol juga diungkapkan informan lainnya "saya pantau terus informasinya, untuk memastikan apa aja yang harus dihindari agar nggak ikutan tertular." Pengakuan dari dua informan tersebut menegaskan bahwa dasar yang mendorong mereka mencari informasi adalah kontrol diri sehingga mereka dapat menjalankan kebijakan Physical Distancing secara baik.

Hasil penelitian juga menggambarkan tentang perilaku informan yang simpati dengan kondisi Physical Distancing. Informan ini tidak terlalu aktif mengakses informasi, akan tetapi hanya menerima saja informasi perihal Physical Distancing. Informan juga mengakui bahwa ia tidak sepenuhnya menjalankan ketentuan Physical Distancing. Kondisi yang dibangun oleh informan sangat kondisional disesuaikan dengan keadaan. Artinya, mereka melakukan tindakan selektif dalam menerapkan Physical Distancing. Misalnya, untuk kerabat dekat, dan orang yang sudah dikenal terkadang aturan jaga jarak tidak diterapkan. "nggak kaku menerapkannya, kadang-kadang aja, liat situasinya, kalau dengan orang yang udah dikenal, saya biasa aja, salaman, ngobrol biasa, ngak ada jaga jarak." Pengakuan informan ini jelas menceritakan tentang bagaimana ia memaknai Physical Distancing sebagai sesuatu yang dinamis, dan menyesuaikan antara konteks dan konten ketika berinteraksi. Namun demikian, informan ini tidak menolak kebijakan, dan juga tidak menerima sepenuhnya Physical Distancing diterapkan. Perilaku informan dalam menyikapi kebijakan jaga jarak ini relevan dengan budaya masyarakat suku Sunda atau masyarakat Priangan (Rosidi, 2000). Masyarakat yang menjunjung tinggi budaya guyub atau kebersamaan. Dilihat dari sudut pandang Cultural Sociology bahwa kebutuhan untuk menyatakan sesuatunya secara tatap muka penting bagi masyarakat Sunda. Namun Physical Distancing ini membuat budaya tersebut terhambat. 
Hasil penelitian juga menggambarkan tentang kondisi informan acuh atau pasif mencari dan mengetahui apalagi menjalankan Physical Distancing. Informan memiliki alasan bahwa tindakan itu diambil karena mereka tidak ingin dibebani oleh perasaan khawatir. Menurut mereka bahwa semakin sering memantau informasi COVID-19 maka akan lebih mengganggu kesehatan mental yang berujung pada gangguan secara fisik. "pas kebetulan aja, nggak diniatkan cari informasi COVID. Biasa aja saya mah, keluar rumah, aktivitas di luar dan masih ngumpul bareng temen-temen." Pengakuan informan ini diperkuat oleh informan lainnya "biasa aja jangan terlalu diikutin, malah nanti jadi stres sendiri dan akhirnya kondisi kita jadi menurun.". Informasi yang disampaikan informan ini dapat diartikan sebagai tindakan pasif dalam mencari informasi. Jika sesekali mereka menerima informasi, maka hal itu hanya dianggap hanya sekedar informasi saja. Ragam konstruksi yang dibangun informan tentang Physical Distancing di atas juga relevan dengan temuan penelitian sebelumnya yang menyebutkan bahwa penerimaan masyarakat terhadap Physical Distancing tergantung motiviasinya. Dalam istilah fenomenologi dapat diartikan sebagai motif tindakan. Adapaun motif yang ditemuan terdiri dari motif Physical Distancing sebagai kontrol diri, empati, dan sekedar informasi (Pfattheicher et al., 2020).

Penelitian ini juga menggambarkan aktivitas informan pada fase Physical Distancing. Berdasarkan hasil wawancara daring, informan mengakui bahwa aktivitas tetap berjalan, namun yang berbeda adalah cara menjalankan aktivitas tersebut. Jika sebelumnya aktivitas di luar rumah diperbolehkan, akan tetapi sejak adanya Physical Distancing berubah bahwa semua aktivitas harus dari rumah. Adapun secara praktiknya aktivitas dilakukan dengan menggunakan teknologi berbasis internet. Sebenarnya, kondisi aktivitas secara daring sudah ada sebelum adanya COVID-19, namun situasinya semakin masif setelah pemerintah mengeluarkan kebijakan Physical Distancing. Akitivitas yang dimaksud meliputi pendidikan, pekerjaan, dan ibadah dilakukan dari rumah atau yang dikenal dengan istilah Work from Home (WfH). WfH merupakan strategi untuk mensukseskan program Physical Distancing. Adanya WfH secara tidak langsung dapat menghentikan aktivitas yang dapat mengumpulkan masa, atau keramaian (Purwanto et al., 2020).

WfH merupakan kebijakan bekerja dari rumah. Kebijakan ini diterapkan di semua institusi, lembaga, organisasi, dan perusahaan. Diakui informan bahwa WfH sangat sulit untuk membangun motivasi kerja. Situasi ini tejadi karena perubahan yang terjadi secara drastis. Masyarakat seolah-olah dipaksa untuk merubah sistem kerja yang sebelumnya dilakukan di luar rumah. WfH tentu saja bisa menimbulkan rasa jenuh, bosan dan lainnya. "Kangen dengan suasana di kantor" senada dengan ungkapan lainnya "Jenuh juga di rumah terus." "Ribet untuk koordinasi, mesti mantengin laptop atau smartphone." Pendapat informan terkait perubahan cara bekerja yang serba dilakukan dari rumah memang bertentangan dengan nilai-nilai masyarakat Indonesia yang memiliki pola budaya tingkat tinggi (high context culture). Pola yang mengedepankan pinsip sopan-santun, etika dalam berkomunikasi (Samovar et al., 2010). Termasuk dalam berkomunikasi masyarakat Indonesia masih mengedepankann komunikasi secara tatap muka yang dinilai lebih menghargai lawan berbicara (Hidayat et al., 2018). 
Perubahan cara beraktivitas memang membuat masyarakat mengalami geger budaya (shock culture). Geger budaya diartikan seagai situasi baru, atau perubahan secara tiba-tiba, sementara masyarakat belum siap menerimanya. Cara kerja dengan sistemWfH telah merubah nilai-nilai yang sudah terbangun kokoh, seperti bekerja sama, bercengkrama di tempat kerja, dan melakukan koordinasi secara tatap muka. Geger budaya juga dipengaruhi oleh kebiasaan masyarakat yang belum akrab dengan budaya industri 4.0. Sebelumnya industri 4.0 memang sudah diperkenalkan, meskipun belum diterapkan karena baru berupa gagasan. Industri 4.0 diartikan pengembangan industri berbasis teknologi (Prasetyo \& Sutopo, 2018). Gagasan 4.0 tersebut harus diterapkan secara masif menyusul adanya pandemi COVID-19. Seiring perjalanan waktu, geger budaya akibat perubahan perilaku selama pandemi COVID-19 dapat diatasi, namun hal ini membutuhkan waktu. Masyarakat perlu beradaptasi dengan sistem dan lingkungan baru yang serba media digital.

Perubahan aktivitas selama fase Physical Distancing juga terjadi dalam konteks pendidikan setelah ditetapkan belajar sistem daring. Sistem ini telah terapkan di seluruh lembaga pendidikan. Sistem belajar daring sama dengan sistem WfH yaitu melakukan aktivitas belajar maupun bekerja berbasis teknologi internet. Pembelajaran daring diartikan sebagai pembelajaran dengan menggunakan media internet. Internet sebagai media pembelajaran dinilai memiliki kelemahan yaitu jaringan. Sangat besar kemungkinan situasi ini terjadi karena pembelajaran daring adalah pembelajaran yang dihubungkan oleh jaringan internet (Cyly et al., 2019). Persoalannya tidak selalu jaringan internet tersebut stabil. Ketika jaringannya lemah, maka mengganggu kualitas pembelajaran. Kondisi serupa seperti yang ditemukan pada penelitian sebelumnya yang dilakukan oleh Mastuti (2016) bahwa ketika jaringan internet bermasalah, maka akan merubah suasana belajar menjadi tidak nyaman (Hidayat \& Noeraida, 2020). Hal serupa dialami oleh informan ketika melakukan perkuliahan daring. Mereka merasa sangat terganggu oleh jaringan internet yang tidak stabil.

Informan sepakat bahwa penerapan Physical Distancing telah melahirkan pengalaman baru berupa komunikasi virtual atau komunikasi daring. Adanya ketetapan jaga jarak dalam berkomunikasi membuat informan memilih berkomunikasi secara virtual. Hal ini tidak saja dilakukan pada orang-orang yang jauh secara jarak, akan tetapi jarak yang dekatpun menggunakan teknologi virtual. "Saya ke tetangga pake whatsapp sekarang, apalagi yang memang jaraknya berjauhan." Informan lain juga mengatakan "Pesen makanan, minta disimpan di pagar, repot akhirnya." Demkian pula pengakuan lainnya "Dengan temen dekat juga pake online semua online dan online bikin bosen juga karena ada saatnya butuh bercengkrama langsung degan orang yang terdekat." Hal senada juga diungkapan bahwa "interaksi online rugi juga selain biaya kuota juga kehangatan jadi berkurang. " Inilah beberapa komentar informan terkait pengalaman mereka selama melakukan komunikasi virtual.

Pengalaman yang diungkapkan para informan di atas selaras dengan hasil penelitian sebelumnya bahwa komunikasi virtual dapat mengurangi kontak sosial dengan orang-orang terdekat. Hal ini menjadi biaya pribadi yang harus ditanggung akibat pandemi COVID-19 (Pratama \& Hidayat, 2020). Komunikasi virtual selama 
Physical Distancing dengan meniadakan pertemuan fisik sehingga merubah dimensi komunikasi interpersonal. Dari orientasi kehadiran fisik menjadi virtual. Padahal komunikasi dengan pertemuan fisik diakui oleh para informan mampu memberikan kepuasan dalam berkomunikasi. Hal ini dimungkinkan karena komunikasi tatap muka dapat menerima feedback secara langsung tanpa melalui media. Komunikasi tatap muka langsung juga menguntungkan proses komunikasi karena adanya keterlibatan pesan verbal dan nonverbal secara maksimal. Temuan ini juga pernah ditemukan pada penelitian sebelumnya bahwa komunikasi antarpribadi atau interpersonal secara tatap muka lebih utama dari bentuk komunikasi lainnya. Komunikasi tatap muka paling efektif dalam menyampaikan pesan (Laurance \& Loisa, 2020).

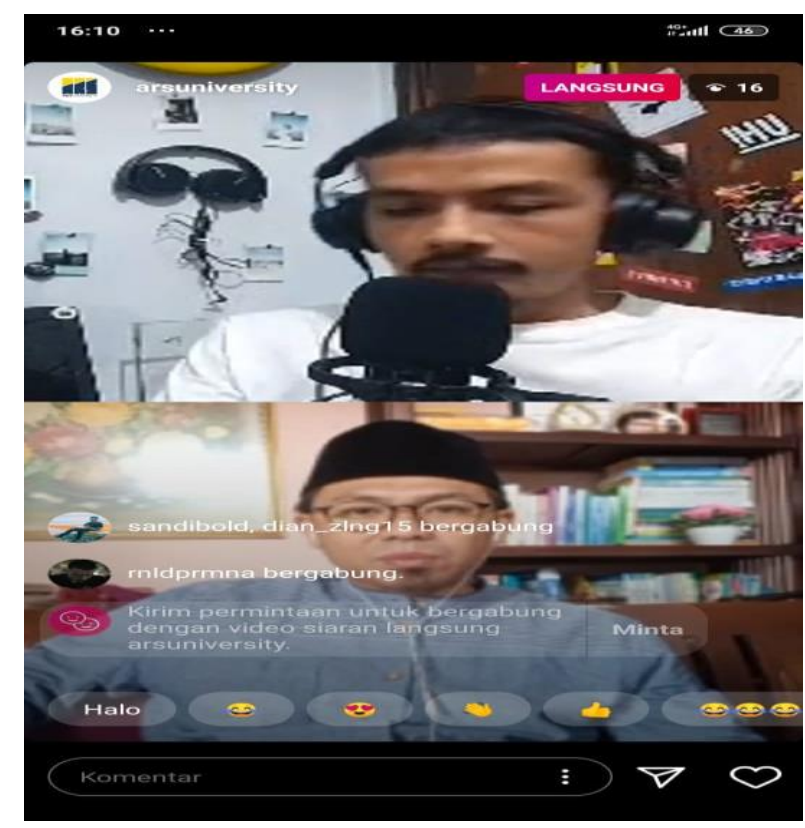

Gambar 2: Komunikasi Virtual

(Sumber: Dokumentasi Peneliti, 2020)

Komunikasi virtual selama fase Physical Distancing lebih menonjolkan proses komunikasi berbasis Informatian Communication and Technology (ICT). Komunikasi dengan perantara jaringan internet untuk menghubungkan antar partisipan komunikasi tanpa mengenal ruang dan waktu. Hal ini sekaligus menjadi kelebihan komunikasi virtual disamping kekurangan yang ditimbulkan. Realitas ini pula yang dirasakan para informan selama melakukan jaga jarak berkomunikasi. Menurut mereka komunikasi virtual tidak selamanya negatif, akan tetapi ada kelebihan yang menjadi ciri khas komunikasi virtual yakni komunikasi lebih fleksibel. "Ada juga kelebihannya, nggak selalu negatif." Selaras dengan ungkapan informan berikutnya "Nggak dibatasi jarak, waktu, diamanapun bisa selama ada jaringan internet." Pengakuan para informan ini juga pernah ditemukan pada penelitian sebelumnya bahwa bekerja dari rumah dengan menggunakan teknologi internet membantu pekerjaan guru lebih dinamis, bisa dilakukan dimana saja, tidak dibatasi waktu jam kerja. Demikian pula halnya yang dirasakan oleh para informan 
selama Physical Distancing. Mereka harus melakukan komunikasi virtual untuk berbagai hal mulai dari pekerjaan, sekolah, perkuliahan, belanja, hingga sekedar untuk silaturahim juga secara virtual. Pengalaman selama melakukan komunikasi virtual, disamping diakui adanya kelemahan, akan tetapi ada pula kelebihannya. Untuk menutupi kekurangan komunikasi virtual, informan menekankan agar peserta komunikasi memperhatikan kompetensi komunikasi atau kemampuan dalam mengelola komunikasi. "sama-sama biar enak yang terlibat dalam komunikasi supaya saling ngerti, dukung." "udah virtual yang ketemu fisik sudah semestinya sama-sama membangun situasi agar kondusif, semua menyesuaikan situasi." Pengakuan informan senada dengan hasil penelitian sebelumnya yang menjelaskan bahwa kompetensi komunikasi daring meliputi aspek empati, itikad baik, adaptasi, interaksi, dan kemampuan mengelola komunikasi (Hidayat et al., 2020). Komunikasi daring diawali dengan masing-masing pihak memberikan porsi empati sehingga mampu mendorong sikap dan perilaku untuk saling menghargai dan mendukung.

Pengalaman terkait perubahan dimensi komunikasi dari kehadiran fisik menjadi virtual, merubah jarak personal menjadi sosial. Realitas ini merubah nilainilai kedekatan, keakraban, berubah menjadi kecemasan, kekhwatiran, bahkan ketakutan dalam berkomunikasi. Masyarakat pada akhirnya selalu dihantaui oleh rasa khawatir ketika berinteraksi dengan teman, kerabat, apalagi dengan orang yang tidak dikenal. Hadirnya dimensi komunikasi virtual selama fase Physical Distancing juga melahirkan model hubungan dunia maya atau hubungan virtual. Istilah lainya disebut pula ikatan sosial secara virtual (Ode \& Nurhaliza, 2020). Pengalaman informan tersebut dikonstruksi sebagai wujud konsensus bersama bahwa hubungan virtual tidak dapat dihindari selama pandemi COVID-19.

Beradasarkan beberapa pengalaman perilaku komunikasi yang diutarakan informan, maka peneliti berpendapat perlu ada upaya untuk menjaga kualitas hubungan meskipun dilakukan secara virtual. Untuk mengimbangi kondisi pandemi yang telah merubah dimensi hubungan, maka diperlukan kompetensi komunikasi bagi tiap individu yang akan melakukan komunikasi. Kompetensi komunikasi secara daring menjadi mutlak di tengah pandemi maupuan pasca pandemi. Kompetensi komunikasi daring dapat diartikan sebagai kemampuan berkomunikasi secara baik melalui media digital (Hidayat et al., 2020). Kompetensi komunikasi daring meliputi empati, itikad baik, adaptasi, interaksi, dan kemampuan mengelola interaksi.

Kemampuan dalam memposisikan diri atau mencoba untuk menjadi lawan berbicara merupakan langkah awal dalam membangun hubungan dengan orang lain. Selanjutnya, ketika berkomunikasi tiap individu juga diwajibkan untuk memiliki kesungguhan atau itikad baik. Adanya itikad baik tentu saja mampu mendorong proses komunikasi sehingga memudahkan pencapaian tujuan. Kemampuan komunikasi juga ditandai dengan hadirnya usaha untuk beradaptasi terhadap lingkungan sekitar, termasuk beradaptasi dengan kemajuan teknologi yang mengharuskan untuk digunakan di tengah pandemi. Empati dan itikad baik merupakan bagian dari aspek afeksi atau emosi yang ada di tiap individu. Sedangkan aspek adaptasi dan interaksi bagian dari kognisi dan perilaku. Kehadiran rasa empati, itikad baik, dan kemampuan adaptasi mendorong kemampuan dalam 
berinteraksi dan mengelolanya sehinga komunikasi dapat berjalan efketif meskipun secara daring. Kompetensi komunikasi daring ini diharapkan mampu menjadi solusi di tengah berbagai hambatan komunikasi daring.

\section{Simpulan}

Berdasarkan pemaparan pada bagian hasil dan pembahasan, maka dapat disimpulkan bahwa semua informan mengetahui tentang Physical Distancing. Informasi Physical Distancing diperoleh dari media konvensional dan media kontemporer. Mereka sangat selektif dalam memilih informasi karena selama pandemi berita hoax ternyata tetap beredar.

Perilaku masyarakat fase Physical Distancing dapat dikategorikan dalam tiga kelompok meliputi informan aktif, simpati, dan acuh. Informan aktif adalah informan yang sadar bahwa informasi Physical Distancing penting sebagai upaya kontrol diri dan keluarga. Sedangkan informan simpati yakni mereka yang tidak terlalu aktif mengakses dan menerima informasi, namun kebijakan Physical Distancing dilakukan meskipun tidak secara penuh, tetapi menyesuaikan situasi. Informan berikutnya adalah informan pasif mencari informasi dan tidak menjalankan Physical Distancing. Kondisi ini terjadi karena mereka meyakini tindakan yang terlalu berlebihan menerima informasi Physical Distancing, justru akan mengganggu mental dan berakhir pada buruknya kondisi fisik.

Aktivitas fase Physical Distancing dilakukan secara daring. Semua aktivitas dilakukan dari rumah dengan cara menggunakan media digital. Informan mengakui bahwa aktivitas Physical Distancing telah merubah dimensi komunikasi interpersonal yang mensyaratkan kehadiran jarak, namun fase Physical Distancing berubah menjadi virtual. Dimensi virtual menonjolkan proses komunikasi berbasis Informatian Communication and Technology (ICT). Perubahan dimensi komunikasi juga merubah jarak berkomunikasi, dari personal menjadi sosial. Aktivitas fase Physical Distancing telah membangun pengalaman bersama bahwa aktivitas secara daring mendorong terbentuknya hubungan virtual.

Hasil penelitian ini diharpakan dapat memberikan kontribusi terkait langkah yang akan diambil pemerintah dalam merumuskan kebijakan Physical Distancing tanpa mengganggu aktivitas masyarakat. Kontribusi dapat berupa peningkatan kemampuan komunikasi khsusunya di dunia pendidikan dan dunia kerja. Lingkungan pendidikan sangat membutuhkan adanya pelatihan komunikasi agar pembelajaran tetap berjalan efektif meskipun secara daring. Demikian pula dengan lingkungan kerja membutuhkan keahlian dalam berkomunikasi sehingga karyawan tetap produktif dan perusahaan bisa bertahan di tengah pandemi.

\section{Ucapan Terima Kasih}

Penelitian ini dilakukan ketika Indonesia sedang mengalami pandemi COVID-19. Situasi ini sangat sulit untuk melakukan pengumpulan data. Namun, berkat kerjasama dan bantuan informan yang bersedia untuk diwawancara meskipun melalui media daring sehigga penelitian dapat diselesaikan. Untuk itu, penulis menyampaikan ucapan terima kasih kepada para informan penelitian, dan 
pimpinan perguruan tinggi yang juga mensuport penelitian ini yakni Universitas Adhirajasa Reswara Sanjaya (ARS University) dan Universitas Telkom (Telkom University).

\section{Daftar Pustaka}

Beniac, D. R., Andonov, A., Grudeski, E., \& Booth, T. F. (2006). Architecture of the SARS coronavirus prefusion spike. Nature Structural and Molecular Biology, 13(8), 751-752. https://doi.org/10.1038/nsmb1123

Cyly, Z., Dalu, A., \& Rohman, M. (2019). Pengembangan E-Learning Sebagai Media Pembelajaran Simulasi dan Komunikasi Digital bagi Siswa SMK. Jurnal Pendidikan Teknik Elektro, 04(1), 25-33.

Eikenberry, S. E., Mancuso, M., Iboi, E., Phan, T., Eikenberry, K., Kuang, Y., Kostelich, E., \& Gumel, A. B. (2020). To mask or not to mask: Modeling the potential for face mask use by the general public to curtail the COVID19 pandemic. Infectious Disease Modelling, 5, 293-308. https://doi.org/10.1016/j.idm.2020.04.001

Fajar, A. (2011). Sistem Kendali dan Strategi Penanganan (Manajemen) Krisis Dalam Kajian Public Relations. Jurnal ASPIKOM, 1(3), 279. https://doi.org/10.24329/aspikom.v1i3.25

Fitri, H., \& Putra, R. B. (2019). The Impact of Learning Culture on Readiness to Online Learning Through Learning Satisfaction as Intervening Variable the Industrial Era 4.0. Jurnal Apresiasi Ekonomi, 7(3), 309-316.

Griffin, E. (2011). A First Look At Communication Theory (T. Z. Ackley (ed.); 8th ed.). McGraw-Hill. http://mhhe.com

Hidayat, D. (2012). Komunikasi Antarpribadi dan Medianya (1st ed.). Graha Ilmu. http://www.grahailmu.com

Hidayat, D., \& Anisti, A. (2015). Wartawan Media Now dalam Mengemas Berita: Perspektif Situational Theory. Jurnal ASPIKOM, 2(5), 295. https://doi.org/10.24329/aspikom.v2i5.81

Hidayat, D., Anisti, Purwadhi, \& Wibawa, D. (2020). Crisis Management and Communication Experience in Education During the CoVid- 19 Pandemic in Indonesia. Jurnal Komunikasi: Malaysian Journal of Communication, 36(3), 67-82. https://doi.org/10.17576/JKMJC-2020-3603-05

Hidayat, D., \& Hafiar, H. (2019). Nilai-nilai budaya soméah pada perilaku komunikasi masyarakat Suku Sunda. Jurnal Kajian Komunikasi, 7(1), 8496.

Hidayat, D., Kuswarno, E., Zubair, F., \& Hafiar, H. (2018). Public Relations Communication Behavior Through a Local-Wisdom Approach: The Findings of Public Relations Components Via Ethnography as Methodology. Malaysian Journal of Communication, 34(3), 56-72.

Hidayat, D., \& Noeraida. (2020). Pengalaman Komunikasi Siswa Melakukan Kelas Online Selama Pandemi COVID-19. Jurnal Ilmu Komunikasi Efek, 3(2), 172-182. https://doi.org/10.32534/jike.v3i2.1017 
Kresna, A., \& Ahyar, J. (2020). Pengaruh Physical Distancing dan Social Distancing Terhadap Kesehatan dalam Pendekatan Linguistik. Jurnal Syntax Transformation, 1(4), 14-19.

La Ode Arwah Rahman, D. I. K. I. P. (2020). OPINI; Physical Distancing dan Budaya Komunikasi. April, 10.

Laurance, J., \& Loisa, R. (2020). Komunikasi Interpersonal Antara Kakak dengan Adik Kandung Berkebutuhan Khusus (Studi Kasus pada Kakak yang Mempunyai Adik Kandung Penyandang Autisme). Koneksi, 3(2), 303. https://doi.org/10.24912/kn.v3i2.6351

Luhukay, M. S. (2013). Penerapan Manajemen Krisis Di Indonesia: Memotret Krisis Dalam Kacamata Public Relations. Scriptura, 2(1), 18-28. https://doi.org/10.9744/scriptura.2.1.18-28

Ode, W., \& Nurhaliza, S. (2020). KOMUNIKASI KELOMPOK DALAM VIRTUAL COMMUNITY. Komunida; Media Komunikasi Dan Dakwah, 10(1), 18-38. https://doi.org/10.35905/komunida.v7i2.http

Pfattheicher, S., Nockur, L., Böhm, R., Sassenrath, C., \& Petersen, M. B. (2020). The emotional path to action: Empathy promotes physical distancing during the COVID-19 pandemic. PsyArXiv [Working Paper], $i$, 1-8. https://doi.org/10.31234/OSF.IO/Y2CG5

Pradsmadji, S. I., \& Irwansyah, I. (2019). Pengalaman dan Pandangan Khalayak Pegiat Sinema Non-Produksi Terkait Teknologi 3D Sebagai Pendukung Saluran Komunikasi Film. Jurnal Komunikasi, 11(2), 141. https://doi.org/10.24912/jk.v11i2.4060

Prasetyo, H., \& Sutopo, W. (2018). Industri 4.0: telaah klasifikasi aspek dan arah perkembangan riset. Jurnal Teknik Industri Universitas Diponogoro, 13(1), $17-26$.

Pratama, N. A., \& Hidayat, D. (2020). Pengetahuan dan Perilaku Masyarakat Memaknai Social Distancing. Jurnal Digital Media \& Relationship, 2(1), $1-10$.

Purwanto, A., Asbari, M., Fahlevi, M., \& Mufid, A. (2020). Impact of Work From Home ( WFH ) on Indonesian Teachers Performance During the Covid-19 Pandemic: An Exploratory Study. International Journal of Advanced Science and Technology, 29(5), 6235-6244.

Rahardjo, W., Qomariyah, N., Andriani, I., Hermita, M., \& Gunadarma, U. (2020). Adiksi Media Sosial pada Remaja Pengguna Instagram dan WhatsApp: Memahami Peran Need Fulfillment dan Social Media Engagement. Jurnal Psikologi Sosial, 18(01), 5-16. https://doi.org/10.7454/jps.2020.03

Rahayu, R. N., \& Sensusiyati. (2020). ANALISIS BERITA HOAX COVID - 19 DI MEDIA SOSIAL DI. Jurnal Intelektiva, 01(09), 60-73.

Rosidi, A. (2000). Ensiklopedi Sunda: Alam, Manusia, dan Budaya. Termasuk Budaya Cirebon dan Betawi. Pustaka Jaya.

Sa'diyah, H. (2013). Manajemen Krisis Universitas Islam Indonesia (UII) Yogyakarta Dalam Mengatasi Kasus Mapala UNISI. Journal of Chemical Information and Modeling, 53(9), 1689-1699. https://doi.org/10.1017/CBO9781107415324.004 
Samovar, L. A., Porter, R. E., \& McDaniel, E. R. (2010). Komunikasi Lintas Budaya; Communication Between Cultures (7th ed.). Salemba Humanika. http://www.penerbitsalemba.com

Sari, W. P. (2020). Studi Fenomenologi Penyelarasan Makna dan Pengalaman Penikmat Warung Kopi di Ambon. Jurnal Komunikasi, 12(1), 124. https://doi.org/10.24912/jk.v12i1.7417

Smith, R. D. (2005). Strategic Planning for Public Relations (2nd ed.). Laurence Erlbaum Asociates Publishers.

Supraja, M. (2012). Alfred Schutz: Rekonstruksi Teori Tindakan Max Weber. Jurnal Pemikiran Sosiologi, 1(2). https://doi.org/10.22146/jps.v1i2.23447

Utami, F., \& Silalahi, B. (2013). Hubungan Antara Identitas Sosial Dan Konformitas Pada Anggota Komunitas Virtual Kaskus Regional Depok. Prosiding PESAT, 5(0), 8-9.

West, R., \& Turner, L. H. (2013). Teori Komunikasi; Pengantar, Analisis dan Aplikasi. Salemba Humanika.

WHO. (2020). \#Covid19 Coronavirus Disease 2019: Situational Report 72. DroneEmprit, 2019(April), 1-19. https://pers.droneemprit.id/covid19/

Yin, R. K. (2014). Study Kasus: Desain dan Metode (1st ed.). Rajawali Pers.

Y1lmaz, H. Ö., Aslan, R., \& Unal, C. (2020). Effect of the COVID-19 Pandemic on Eating Habits and Food Purchasing Behaviors of University Students. 15(3), 154-159. https://doi.org/10.21109/kesmas.v15i3.3897

Yunus, N. R., \& Rezki, A. (2020). Kebijakan Pemberlakuan Lock Down Sebagai Antisipasi Penyebaran Corona Virus Covid-19. SALAM: Jurnal Sosial Dan Budaya Syar-I, 7(3). https://doi.org/10.15408/sjsbs.v7i3.15083 